\title{
Infrastructure in South Africa: Who is to finance and who is to pay?
}

\author{
ESTIAN CALITZ AND JOHAN FOURIE
}

\section{Stellenbosch Economic Working Papers: 15/07}

KEYWORDS: INFRASTRUCTURE FINANCING, GOVERNMENT LOANS, BENEFIT TAXATION, GUARANTEES, PRIVATE-PUBLIC PARTNERSHIPS, SOUTH AFRICA JEL: H54, H81, H72

ESTIAN CALITZ EXECUTIVE DIRECTOR: FINANCE UNIVERSITY OF STELLENBOSCH PRIVATE BAG X1,7602 MATIELAND, SOUTH AFRICA E-MAIL: CALITZ@SUN.AC.ZA
JOHAN FOURIE DEPARTMENT OF ECONOMICS UNIVERSITY OF STELLENBOSCH PRIVATE BAG X1, 7602 MATIELAND, SOUTH AFRICA E-MAIL: JOHANF@SUN.AC.ZA 


\section{Infrastructure in South Africa: \\ Who is to finance and who is to pay?*}

ESTIAN CALITZ AND JOHAN FOURIE**

ABSTRACT

Against the backdrop of shifting views on the role of government in the provision of infrastructure, this paper distinguishes between the payment for and financing of the South African Government's infrastructure investment programme. The paper also presents a classification system that enables a systematic mapping of all prospective projects, with reference to considerations of efficiency and equity. This mapping should assist in macro planning and in any analysis of the financial implications of project financing and cost recovery at all levels of government. The government's financing strategy is questioned and alternatives are identified. The prospects for mobilising funds other than tax revenue are assessed, namely government loans, private equity, development finance and donor funds. Four investment projects are considered with a view to testing the classification system and evaluating the chosen financing options in terms of economic criteria.

Keywords: Infrastructure financing, government loans, benefit taxation, guarantees, privatepublic partnerships, South Africa

JEL codes: H54, H81, H72

\footnotetext{
* Paper to be presented at the bi-annual Conference of the Economic Society of South Africa, Johannesburg, September 2007.

** Estian Calitz is Executive Director: Finance and Professor of Economics and Johan Fourie is a Lecturer in Economics at Stellenbosch University.
} 


\section{Infrastructure in South Africa: \\ Who is to finance and who is to pay?}

In terms of the Accelerated and Shared Growth Initiative of South Africa (ASGISA) (RSA, 2006), the 2006 National Budget envisaged that R415,8 billion will be invested in infrastructure over a three-year period (National Treasury, 2007: 45). This investment surge is to follow the previous period of major cutbacks in public-sector investment ${ }^{1}$, an important though not undisputed factor in the successful decade-long attempt at restoring fiscal sustainability. A breakdown by year and expenditure entity is given in Table 1.

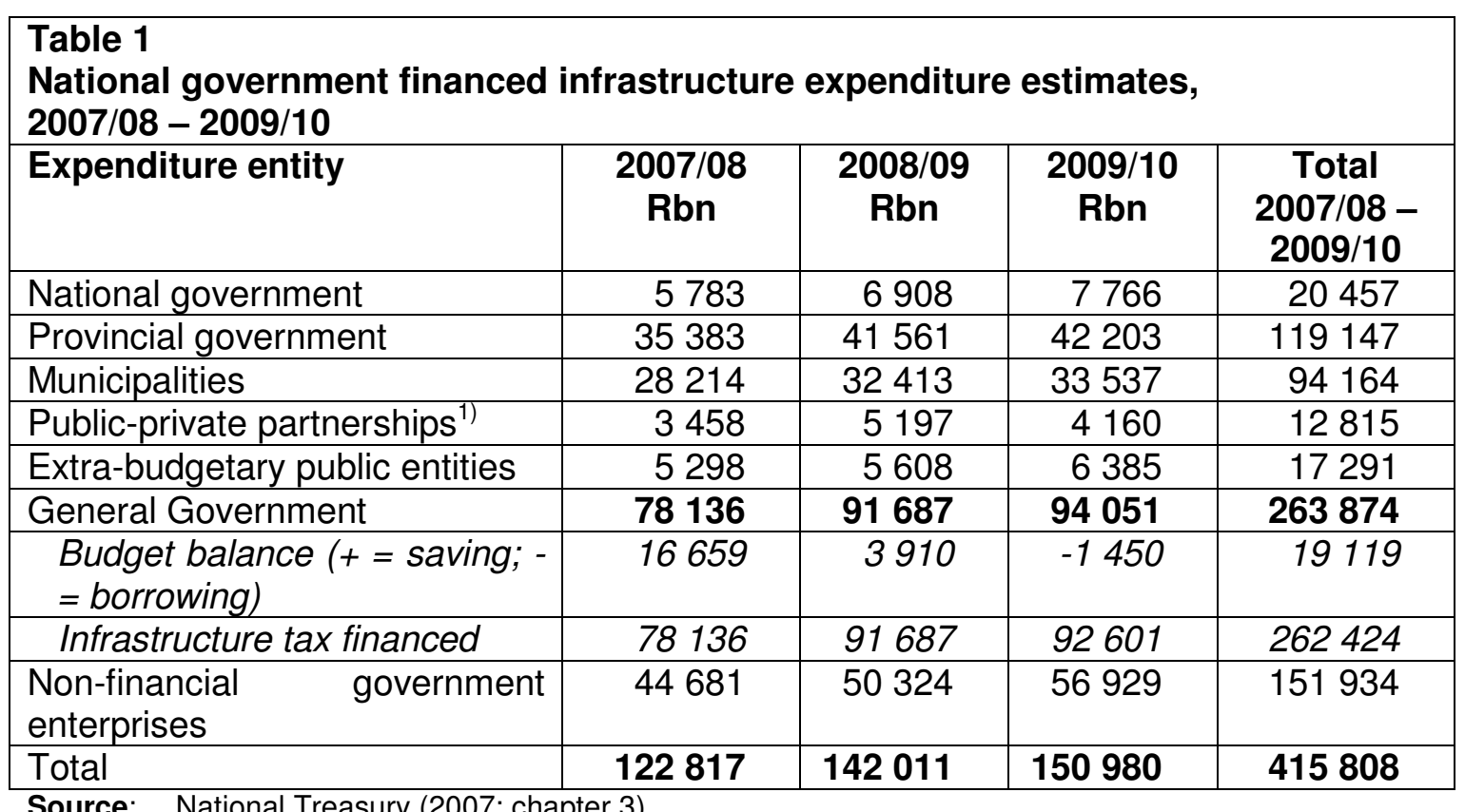

Notes: 1) Capital expenditure on PPPs overseen by the Treasury PPP Unit, SA National Roads Agency, Department of Public Works and at municipal level. PPP's only reflect private sector contributions.

The pivotal role accorded to public investment in ASGISA raises questions that during the past two decades have generated increasing research interest in infrastructure and its proper financing. Research is concerned with questions such as: what are the financing needs of infrastructure; how much scope is there for private participation in infrastructure financing; how much fiscal space do governments have to meet infrastructure financing needs; and what should drive the new wave of financing mechanisms? (Estache, 2004: 7). In many respects these questions boil down to two important questions: how is this infrastructure expansion to be financed and who is eventually to pay?

We are reminded that the answers to these two questions are not only important for reasons of allocative and technical efficiency, but also because of certain distinctive economic characteristics of infrastructure - a high capital intensity, externalities, elements of natural monopoly, and locationspecific investments - all of which affect the nature and extent of government involvement and private sector incentives to commit long-term capital (World Bank, 2006: 150).

Table 1 implies that 63.4 per cent of the envisaged investment during the three-year period will be financed by the three tiers of government collectively known as the general government. Of the total of general government investment, almost R140bn will be undertaken by national and provincial government. Government (RSA 2007: 3) predicts a main budget surplus of 0.3 per cent

\footnotetext{
${ }^{1}$ The general government's contribution to gross capital formation, which had reached its highest post-1960 level of 10,6 per cent in 1976, then decreased steadily, reaching a low of 2,4 per cent in 1992 and remaining low during the 1990s. Only during the first half of the current decade were there signs of a turnaround. During 2000-2004 general government capital formation averaged 2,8 per cent of GDP, with indications of a further upward trend towards the end of the period. In addition, persistent (albeit decreasing) general government dissaving reduced the pool of savings that is available for investment to expand the productive capacity of the economy. See Calitz and Siebrits (2005: 255).
} 
in 2006/07 and 0.6 per cent in 2007/08, moving to deficits of 0.1 per cent in 2008/09 and 0.4 per cent in 2009/10. Given that virtually no borrowing occurs within provinces, this implies that the infrastructure will on balance be financed by current revenue (tax income). The investment by nonfinancial enterprises will be financed through non-tax income. It is unclear whether municipal infrastructure will be financed through intergovernmental transfers, local taxes or user charges.

This likely scenario raises a few questions. Why would the Government pay in cash (i.e. use current tax revenue) for infrastructural investment, which has a long economic lifetime and of which the benefits arguably straddles more than one generation of tax payers? What other options are available and what are their advantages and disadvantages?

\section{Towards an understanding of the Government's infrastructure financing strategy}

The Government's short-term macroeconomic strategy apparently inter alia aims at softening the risks associated with the relatively high current account deficit. Fiscal restraint in the form of a balanced budget or even a surplus is a key element. The aim clearly is to neutralise the inflationary consequences of high domestic spending and current account pressures on the external value of the home currency. The high import content of much of the envisaged infrastructural investment and the scarcity predicted for certain inputs and skills are likely to add further cost pressures (SUDEO International Business Consultants, 2007: iii-iv). The longer-term objective apparently is to increase the national propensity to save: the financing of the envisaged national and provincial infrastructural investment within a balanced budget should directly increase the savings rate by about 2.6 percentage points.

The above approach can be questioned from different angles. Economic theory suggests two reasons for financing infrastructure through loans, rather than taxes. They are intergenerational equity and the associated application of the benefit principle for purposes of allocative efficiency, and Keynesian activism for purposes of macroeconomic stabilisation. The strongest arguments against loans are the neoclassical argument of crowding-out and the public choice leviathan argument. In recent times fiscal rules have gained popularity as a reaction to the disillusion with fiscal discretion, even though it has been argued that fiscal rules are unlikely to add credibility benefits to fiscal discretion cum transparency-enhancing measures (Siebrits and Calitz, 2003: 781). Standard fiscal rules adopted to ensure debt sustainability as part of macroeconomic adjustment programmes are increasingly being criticized, however, as excessively binding constraints on appropriate countercyclical action (Estache, 2004: 13). To the extent that the South African Government has reduced the budget balance below the levels required for macroeconomic stability, underutilised fiscal space exists. ${ }^{2}$ This would allow for at least two other fiscal options or a combination thereof, without incurring government dissaving. The Government could resort to loan finance that matches the total annual capital spending, which will enable the launching of more projects than under cash financing. Another option would be to reduce the tax burden.

We now explore the financing of infrastructure from an allocative and distributional point of view.

The Government's financing strategy implies the application of the ability-to-pay approach, which severs the link between the user of the infrastructure and the person or entity who pays for it. Moreover, the strategy implies that a major part of the infrastructure has to be financed via the budgets of the three tiers of government. This raises two related questions: should government be the financier and should tax payers foot the bill? The first question has to do with the assignment of responsibilities for the financing of infrastructure in a market-based economy (i.e. are the infrastructural facilities public goods?); the second with the appropriate incidence of the cost.

Table 2 allows for an inspection of the type of infrastructure to be supplied. It shows that economic infrastructure constitutes almost 80 per cent (see subtotal 1) of the total of the expenditure estimates which the Government identified as key capital/infrastructure. If housing is added, the ratio is almost 90 per cent (see subtotal 2). The cost of all of these can arguably be recouped from individual end users, rather than tax payers, by applying the benefit principle rather than the ability-

\footnotetext{
${ }^{2}$ For a discussion of the nature of fiscal space in relation to fiscal sustainability, see Heller (2005b).
} 
to-pay principle.

\begin{tabular}{|l|r|r|}
\hline $\begin{array}{l}\text { Table 2 } \\
\text { Key capital/infrastructure expenditure estimates, 2003/04-2009/10 }\end{array}$ \\
\hline Type of infrastructure & $\begin{array}{r}\text { Total } \\
\text { Rm }\end{array}$ & $\begin{array}{r}\text { \% of } \\
\text { total }\end{array}$ \\
\hline Water (DWAF, water boards, TCTA and municipal) & 27.3 & 9.0 \\
\hline Sanitation (municipal and DWAF) & 9.5 & 3.2 \\
\hline Electricity (Eskom and municipal) & 71.3 & 23.5 \\
\hline Roads (SANRAL, provincial and municipal) & 62.2 & 20.5 \\
\hline Rail (SARCC, Gautrain and Spoornet) & 46.1 & 15.2 \\
\hline Ports (NPA and SAPO) & 16.6 & 5.5 \\
\hline Sport \& Recreation (World Cup stadiums) & 7.8 & 2.6 \\
\hline Subtotal 1 & 240.5 & 79.5 \\
\hline Housing (housing developments) & 29.6 & 9.8 \\
\hline Subtotal 2 & 270.1 & 89.3 \\
\hline Education (school building) & 11.6 & 3.8 \\
\hline Health (hospitals and clinics) & 16.3 & 5.4 \\
\hline Justice (courts ) & 1.3 & 0.4 \\
\hline Police & 3.3 & 1.1 \\
\hline Total & $\mathbf{3 0 2 . 8}$ & $\mathbf{1 0 0 . 0}$ \\
\hline
\end{tabular}

Source: National Treasury (2007: 45).

\section{Alternatives or supplements to the Government's choice}

From an efficiency point of view, the traditional view as to whether and to what extent government should assume responsibility for the provision (read: financing) of public goods has shifted substantially over the past few decades. Infrastructure provides public services and therefore assumes some kind of public sector involvement. Three types of market failures are relevant to infrastructure provision - public goods (goods with the usual characteristics of non-rivalry and nonexcludability), externalities (marginal private benefit is smaller than the marginal social benefit) and incomplete markets (of which natural monopolies with decreasing average costs are the best example). Each requires different ways of government intervention: pure public goods require government to prompt the process and incur the cost of provision, while externalities and incomplete markets may require government in a more regulatory role. It is important that a government does not assume an inappropriate role, nor expects inappropriate involvement of private business, a balancing of responsibilities and associated risk incidence which is easily misjudged and which could jeopardize the outcome.

Different market failures also necessitate different methods of budgeting and means of financing. Traditionally, pure public goods (such as street lights, highways and water storage) are financed by government through present or future taxation, with no or partial user charge cost recovery. Positive externalities and natural monopolies create opportunities for benefit taxation through user charges or earmarked taxes, with or without government or private loan finance, while the use of private equity occurs where private-public partnerships are found in natural monopolies, as increasingly happens.

Of course, the respective roles of government and private business are shifting with changing technology and innovation. Figure 1 is an attempt to illustrate that the traditional public finance view, in terms of which little if any infrastructure provision was seen to be provided by the market, has shifted to a view which accords a bigger responsibility to the market. The ICT revolution, the development of competitive markets and a better understanding of different ways in which market competition can be simulated, played a role.

Examples abound: in electricity generation, the advancement of solar- and wind-powered generators are shifting electricity production from the traditional viewpoint towards private ownership and management, a move brought about by lower fixed costs and smaller economies of scale. In telecommunications, cellular technology has all but removed the natural monopoly fixedline operator while new privately operated ports and airports show that innovative market design 
can shift pure public good properties into the realm of mixed or private goods.

Figure 1

Shifting view on the publicness of infrastructure

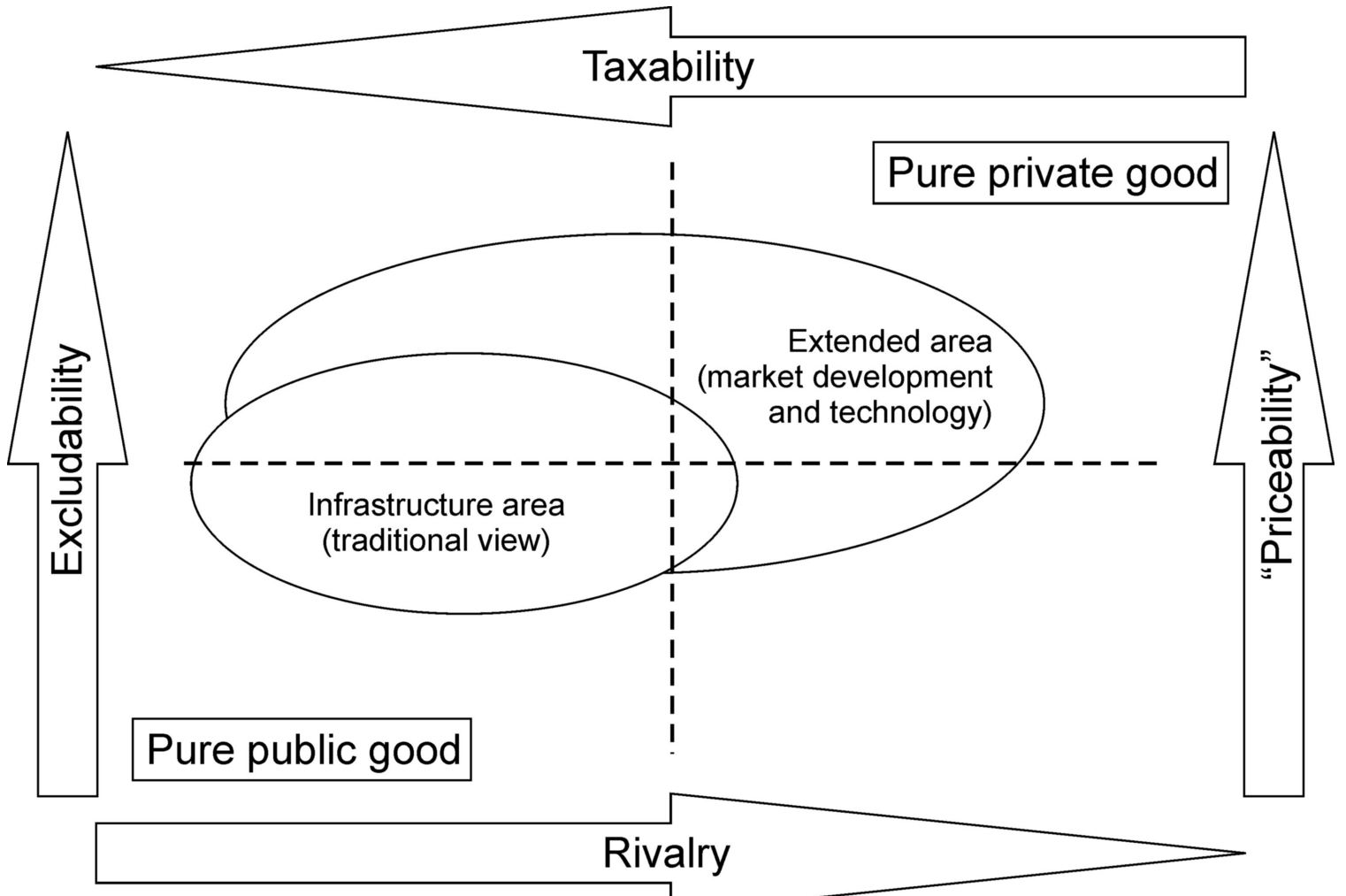

Source: The authors

More importantly, the shift towards rival and excludable infrastructure goods has also reshaped the traditional view of infrastructure financing. Figure 1 shows that because excludability has increased and rivalry can be simulated to a greater degree, the ability to determine a price (user charge) has gained field on taxation. Consequently, a much larger range of goods and services (including infrastructure) traditionally classified as tax-financed public goods, are now regarded as "priceable" self-financing activities within or outside of government budgets. This is depicted by an expansion of the "infrastructure ellipse" in Figure 1, towards the top (indicating a greater measure of excludability) and to the right (more rivalry); in combination this implies greater private sector involvement. Of course, a change in the finance mechanism also has distributional implications, to which we refer later.

The South African Government has apparently decided to use taxes to finance a major part of the planned infrastructure investment, in contrast with other possibilities suggested by current mainstream economic thinking and international experience. We suggest that one way to identify the alternatives is with reference to the different organisational forms in which public infrastructure might be provided.

- If the activity forms part of the functions of a national, provincial or local government and is financed (in cash) within the annual budget, the financing will be effected either through reprioritisation, additional taxes or loan finance. In the case of loan finance, the loan is likely to be serviced through future tax revenue and/or user charges. Multilateral development finance may be a supplementary source.

- If the activity is the responsibility of a designated government agency other than a normal government department (e.g. a water board, a public enterprise such as Transnet or a public corporation such as Eskom), internal financing (if accumulated reserves are available) and external financing (loans or equity) - domestic or foreign - are the indicated 
sources. User charges will take care of the debt servicing and the operational cost. Government intervention may be in the form of interference with price setting (such as prescribing an internal subsidisation by high-income users of low-income users). Conversely, the entities may attempt to obtain government loans or guarantees to reduce private-sector loan cost. Multilateral development finance may again be a supplementary source, whilst guarantees from an institution like the World Bank can play a role.

- If the activity is the responsibility of a private business entity (either on its own or in partnership with a government agency), loan finance may be complemented by equity finance. Business and political risk may again prompt the seeking of government guarantees or the allowance of sufficiently large profit margins. The latter is a particularly thorny issue when a public monopoly is replaced by a private one and price sensitivity is great, especially when there are a large number of low-income users. A government's inclination to regulate prices often results in the withdrawal or non-supply of private equity and even in a loss of private interest in running the business. The results of a study by Kirkpatrick, Parker and Zhang (2006: 143) indicate "that FDI in infrastructure responded positively to an effective domestic regulatory framework. By implication, where regulatory institutions are weak and vulnerable to 'capture' by the government (or the private sector), foreign investors may be more reluctant to make a major commitment to large scale infrastructure projects in developing countries."

We now explain the different options with reference to Table 3, which distinguishes between incidence of cost (columns) and source of finance (rows). In each cell the underlying economic consideration is given in brackets at the end of the brief description of the financing and payment position. This classification is useful when we explore different financing options as case studies at the end of the paper.

\begin{tabular}{|c|c|c|c|c|c|c|}
\hline \multicolumn{7}{|c|}{$\begin{array}{l}\text { Table } 3 \\
\text { Paying for versus financing of infrastructure spending }\end{array}$} \\
\hline & & & \multicolumn{4}{|c|}{ Who pays } \\
\hline & & & Tax payer & \multicolumn{2}{|c|}{ User } & \multirow[t]{2}{*}{ Donor } \\
\hline & & & & $\begin{array}{l}\text { As per } \\
\text { benefit }\end{array}$ & $\begin{array}{c}\text { Cross- } \\
\text { subsidisation }\end{array}$ & \\
\hline & & & 1 & 2 & 3 & 4 \\
\hline \multirow[t]{3}{*}{$\begin{array}{l}\text { Who } \\
\text { finan- } \\
\text { ces }\end{array}$} & $\begin{array}{l}\text { Tax payers } \\
\text { (cash) }\end{array}$ & $a$ & $\begin{array}{l}\text { Financed and } \\
\text { paid for by tax } \\
\text { payers (as if } \\
\text { public } \\
\text { consumption) }\end{array}$ & $\begin{array}{l}\text { Financed by } \\
\text { tax payers; } \\
\text { users pay } \\
\text { (benefit } \\
\text { approach) }\end{array}$ & $\begin{array}{l}\text { Financed by } \\
\text { tax payers; } \\
\text { certain users } \\
\text { subsidise } \\
\text { others } \\
\text { (distributional) }\end{array}$ & $\begin{array}{l}\text { Financed by } \\
\text { tax payers; } \\
\text { donors bear } \\
\text { part of cost } \\
\text { (distributional) }\end{array}$ \\
\hline & $\begin{array}{l}\text { Lenders to } \\
\text { government } \\
\text { or } \\
\text { government } \\
\text { enterprises } \\
\text { (loans or } \\
\text { guarantees) }\end{array}$ & $\boldsymbol{b}$ & $\begin{array}{l}\text { Loan financed } \\
\text { by private } \\
\text { investors; tax } \\
\text { payers repay } \\
\text { loans over time } \\
\text { (intergenera- } \\
\text { tional equity; } \\
\text { allocative } \\
\text { efficiency) }\end{array}$ & $\begin{array}{l}\text { Financed by } \\
\text { private } \\
\text { investors; } \\
\text { users repay } \\
\text { loans (inter- } \\
\text { generational } \\
\text { equity; } \\
\text { allocative } \\
\text { efficiency) }\end{array}$ & $\begin{array}{l}\text { Financed by } \\
\text { private } \\
\text { investors; } \\
\text { users subsidise } \\
\text { others } \\
\text { (distributional) }\end{array}$ & $\begin{array}{lr}\text { Financed } & \text { by } \\
\text { private } & \\
\text { investors; } & \\
\text { sponsors } & \text { pay } \\
\text { (subsidise } & \text { tax } \\
\text { payers } & \text { or } \\
\text { users) } & \end{array}$ \\
\hline & $\begin{array}{l}\text { Private } \\
\text { investors } \\
\text { (equity) }\end{array}$ & c & $\begin{array}{l}\text { Equity financed } \\
\text { by private } \\
\text { investors; tax } \\
\text { payers pay to } \\
\text { effect return on } \\
\text { investment } \\
\text { (public-private } \\
\text { partnership) } \\
\text { (equity; } \\
\text { allocative } \\
\text { efficiency) }\end{array}$ & $\begin{array}{l}\text { Equity } \\
\text { financed by } \\
\text { private } \\
\text { investors; } \\
\text { users pay to } \\
\text { effect return } \\
\text { on } \\
\text { investment } \\
\text { (benefit } \\
\text { approach; } \\
\text { allocative } \\
\text { efficiency) }\end{array}$ & $\begin{array}{l}\text { Equity financed } \\
\text { by private } \\
\text { investors; } \\
\text { users pay and } \\
\text { subsidise } \\
\text { others to effect } \\
\text { return on } \\
\text { investment } \\
\text { (distributional) }\end{array}$ & 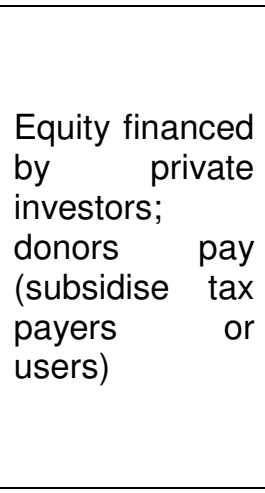 \\
\hline
\end{tabular}




\begin{tabular}{|c|c|c|c|c|c|}
\hline $\begin{array}{l}\text { Development } \\
\text { agencies } \\
\text { (loans) }\end{array}$ & $d$ & $\begin{array}{l}\text { Loan finance } \\
\text { by } \\
\text { development } \\
\text { agencies; tax } \\
\text { payers pay to } \\
\text { effect debt } \\
\text { service }\end{array}$ & $\begin{array}{l}\text { Loan finance } \\
\text { by } \\
\text { development } \\
\text { agencies; } \\
\text { users pay to } \\
\text { effect debt } \\
\text { service }\end{array}$ & $\begin{array}{l}\text { Loan finance } \\
\text { by } \\
\text { development } \\
\text { agencies; } \\
\text { users subsidise } \\
\text { others } \\
\text { (distributional) }\end{array}$ & $\begin{array}{l}\text { Financed and } \\
\text { paid for by } \\
\text { development } \\
\text { agencies } \\
\text { (equity) }\end{array}$ \\
\hline $\begin{array}{l}\text { Donors } \\
\text { (grants) }\end{array}$ & $e$ & $\begin{array}{l}\text { Grant finance } \\
\text { reduce cost to } \\
\text { tax payers }\end{array}$ & $\begin{array}{l}\text { Grant finance } \\
\text { reduce cost } \\
\text { to users }\end{array}$ & $\begin{array}{l}\text { Grant finance } \\
\text { reduce } \\
\text { subsidisation } \\
\text { by users to } \\
\text { other users }\end{array}$ & $\begin{array}{l}\text { Grants by } \\
\text { sponsors } \\
\text { (financed and } \\
\text { paid for) } \\
\text { (philanthropic; } \\
\text { equity) }\end{array}$ \\
\hline
\end{tabular}

The cost of infrastructure is ultimately borne by either tax payers, users or donors (columns 1,2, 3 and 4). The responsibility, if not obligation, of tax payers remains important to the present day, long after Adam Smith, in his Wealth of Nations (1776) noted that "the duty of erecting and maintaining certain public works and certain public institutions which it can never be for the interest of any individual, or small number of individuals, to erect and maintain" falls to the state, "because the profit could never repay the expense to any individual or small number of individuals, though it may frequently do much more than repay it to a great society" (Smith, 1776: IV: 9.V.1.87) ${ }^{3}$.

If the nature of the facility is such that the benefits can be attributed to identifiable users (i.e. low external benefits of costs), user charges are indicated. If low-income users are to be subsidised, certain users will pay more than the benefit received in using the infrastructure (column 3 ). When donors bear part of the cost (column 4), tax payers, users or a subgroup of users are the beneficiaries. Of course, as with all transfer payments, the ability to substitute nonsubsidised goods or tax obligations for subsidised goods means that the intended beneficiaries may not be the eventual beneficiaries. ${ }^{4}$

A number of financing sources are available, as listed in the rows in Table 3. The infrastructure can be paid for in cash (row a), through the national, provincial or local budget (which represents the SA Government's current position, as in cell 1a). Loan finance could be used by Government or government business enterprises, the latter with or without government guarantees (row $b$ ). Loans can be in the form of bulk lending for a composite set of projects or project loans. Private individuals or companies are the financiers. The investment plans of public enterprises typically fall in this category. Equity investment is another source of finance (row c): private business(es) buys a share (either as owners, co-owners or in partnership with government) in the activity, which needs to be properly structured for that purpose. Development agencies are another source of finance (row d). This normally entails cheaper loan finance either because the borrower receives the benefit of cheaper rates which the bulk lender can negotiate in the financial market, or because deliberate subsidisation is provided. In the latter case, some or other sponsor bears a portion of the cost of the infrastructure (as in cell 4d). Finally, donors can be a source of finance (row e), in which case grants reduce the cost to whoever has to pay for the infrastructure.

Next we assess the merits and feasibility of the various options. We do not regard donor funds as a major source of finance for a planned long-term infrastructure expansion and therefore we focus only on the first four sources of finance in Table 3, namely, tax payers (government), lenders, equity investors and development agencies (which of course ultimately represent some tax payer or another or private philanthropist).

Should loan finance be considered (row $b$ in Table 3)? This brings us back to the question about the appropriateness of South Africa's budget surplus, which appears to represent a tradeoff

\footnotetext{
${ }^{3}$ Notation refers to Book IV, Chapter 9, Paragraph V.1.87

${ }^{4} \mathrm{See}$ in this regard the standard fiscal literature on the effect of intergovernmental grants on the choice by the recipients between the consumption of subsidised public goods and consumption goods (i.e. tax reduction) (e.g. Rosen, 2005: 532536). By inference, the same analysis can be used to show that grant money to reduce the cost of infrastructural projects can distort relative prices and change the preferences of recipients in such a way that the actual benefit and its incidence may differ from what was intended.
} 
between growth and inflation. There is an implied and contestable reasoning that government investment is dependent on government savings which plays in to the hands of those who believe that savings determine rather than respond to investment, sector by sector. The correction for the observed failures of deficit spending need not be that the government should only rely on its own savings to finance investment (i.e. running a current budget surplus equivalent to the amount of capital expenditure). Another surplus-budget argument is that countries in which nonrenewable resources are depleted should in this manner accumulate financial wealth (e.g. commensurate with the rate of depletion) to compensate future generations for the bequest of reduced natural wealth, as in the case of Chile. If this was a consideration in the justification of the surplus envisaged for the general government sector in 2007/08 and 2008/09 (see National Treasury, 2007: 49), at least it was not revealed as such. There is one other possible explanation for the planned budget surplus, namely an insurance policy against an over-optimistic projection of the enhanced economic growth that the ASGISA may generate. In other words, the fall-back position may well be to incur a growing budget deficit by default which, when it happens, will actually vindicate the view that considerations of macroeconomic stability provided such fiscal space. A proper disclosure up front of this contingency, which may well be the most acceptable of the above three explanations, would certainly benefit fiscal credibility. Whatever the reason(s), the long economic lifespan of infrastructure nonetheless justifies loan finance from the point of view of intergenerational equity and allocative efficiency, a microeconomic argument at variance with the Government's macroeconomic stability considerations.

However, even if the Government wishes to maintain a budget surplus, this need not close the door for loan finance. The more users rather than tax payers are to bear the cost (as in column 2) and the activity is structured and financed as a self-financing project outside the national, provincial or municipal budget, the more additional fiscal space will be created in the budget, whatever the target for the budget balance. Loan financing will ensure (better) intergenerational equity. From an efficiency point of view, this benefit approach to financing the facility should be superior to a government investment programme financed from consolidated tax revenue and run administratively and possibly without financial performance criteria. Already government enterprises operate in this manner (line b), but with intelligent project design more infrastructural facilities could be offered in this way (see the list of key areas in Table 2). Given that the benefits of infrastructural projects at local and even provincial government level are often geographically confined, such projects may be good candidates. Should distributional considerations require a subsidy to ensure affordability, this could be either tax financed (as in cell 1a, although tax payers will then only bear part of the cost) or paid for by higher-income users (i.e. cross-subsidisation within the group of users, as in cell $3 b$ ).

\section{Private investment}

Private investment does not mean that the investor bears the burden of the cost, unless of course - in the case of equity investment - a loss is made. What is the likelihood of mobilising more domestic or foreign private investment, either in the form of loan or equity finance (rows 2 and 3 )? This question has a bearing on both the investment by government business enterprises and the kind of "on-budget" projects alluded to in the previous paragraph. Already there are good examples, e.g. Aeroporti de Roma's 20 per cent share in the Airport Company of South Africa (of which the SA Government owns $74.6 \%$ ) and the investment of private consortiums in government infrastructure (via the Development Bank of Southern Africa) (see the section on development finance below). International experience has shown that business or project design, the regulatory environment and risk management are among the key success factors. What is the international experience?

The review in recent times of the relative responsibilities of government and private business in the construction, financing and operation of infrastructure facilitated a major transition to private participation in infrastructure, but the transition has not yet settled. The World Bank (2004: 154) points out that in many developing countries the agenda of market liberalisation, regulatory reform, and the restructuring of state-owned monopoly utilities remains unfinished. The Bank argues that, given the characteristics of certain infrastructure industries, including the huge sunk costs involved, elements of natural monopoly, and their political saliency, there remains a strong rationale for state intervention, even in cases where privatisation has been completed. In addition, investors have to 
factor in ongoing transformations of the global infrastructure industry, such as how to accurately price and gauge demand for new products resulting from rapid technological change.

From an investor's point of view, the decision to invest in an infrastructure project depends on a number of considerations, such as:

- the respective rates of return, which vary with market conditions;

- the gearing opportunities which depend on market conditions as well as the investment strategy of the prospective investor;

- the complementary business opportunities;

- the regulatory environment/framework; and

- the risk factor, which in addition to the standard risk elements, inevitably contains a political dimension because of the public- or quasi-public goods characteristics of infrastructure, especially if profit margins (and prices) become suspect under conditions of ineffective competition.

These considerations not only determine the decision to invest, but also the nature of investment, i.e. equity or loan investment and whether to invest in another country. The prospective investor's interest in the particular sector (e.g. telecommunications or energy) or the particular country (if foreign investment is contemplated) then comes into play.

After World War II, most infrastructure assets were vertically and horizontally integrated state monopolies under ministerial control (Kessides 2004: 1). However, since the early 1990s there has been a worldwide change in how infrastructure should be owned, organised and regulated. Alexander and Estache (1999: 2) point out that this change occurred because governments found that their own resources were insufficient to meet the growing infrastructure demands, they were under pressure to use their scarce resources for other government services such as welfare, and there was a belief that the private sector operators would bring about greater efficiency. To effect private participation, institutional reforms entailed a combination of competitive restructuring, privatisation, and the establishment of appropriate regulatory mechanisms (Kessides 2004: 3). Since the mid 1980s South Africa underwent similar reforms, preparing the way for the gradual commercialisation and privatisation of state-owned enterprises, a process that is still underway.

Estache (2004: 9) observes that during much of the 1990s infrastructure policies in developing countries were based on the assumption that financing was going to be rebalanced from its two traditional sources - the public sector (government or public utilities) and official development assistance - toward a third source: the private sector. The rebalancing did not go as far as many had hoped, particularly in the lowest-income countries and in the poorest regions of middle-income countries. During the 1990s the public sector financed 70 per cent, the private sector 20-25 per cent, and official development assistance 5-10 per cent of infrastructure spending, but these are rough estimates because the required data are not available.

Internationally, the private investment experience with regard to infrastructure has been rather varied. Da Silva, Estache and Järvelä (2006: 90-91) found evidence that debt has been replacing equity in the financing of the investment needs of utilities and transport services in developing countries. They found that leverage rates vary significantly across sectors, with the highest rates observed in transport and the lowest in water. One of the main motivations of the infrastructure privatisation wave of the 1990s was to obtain a significant contribution from the private sector to the financing of the major investment needs of the poorest countries. Reforms, restructuring and guarantees were generally aimed at maximising the access to private investment. A large number of developing countries did in fact introduce private participation into their infrastructure industries and, by the end of 2001 , developing countries had received over $\$ 755$ billion in private investment flows in nearly 2,500 infrastructure projects (World Bank, 2003: v). More specifically, this meant reorganising the sector to achieve a significant equity contribution in the financing of the new projects.

Investment commitments peaked in 1997 and have since continued to drop. The 2002 figures represented the lowest level of investment commitments in projects with private sector participation 
since $1994 .^{5}$ This was accompanied by a significant reduction in the number of projects reaching financial closure. There was a growing concern that the financing structure adopted by the operators may be increasingly switching from equity to private, mostly foreign, debt financing. Such a switch was likely to be difficult for two reasons. First, to developing countries debt finance can be more expensive than equity finance when the transaction costs associated with the effective shortterm nature of the bonds market in developing countries is accounted for. Second, every unit of foreign currency that enters into a country would be matched by a much larger proportion of debt contracted by the private operators. The public debt needed to finance the operations in the past would then be replaced by private debt rather than by private equity. Besides the obvious balance of payment consequences, this evolution in the financing structure of the sector raised significant issues from the strict viewpoint of regulation. Indeed, higher risks, higher cost of capital and hence higher tariffs are implied by two things: more expensive debt and operators more leveraged in foreign currency.

Research on the experience with private finance of infrastructure concludes that the cost of doing business in developing countries is a key success factor. This outcome is consistent with the fact that this cost has been much higher than expected. Estache and Pinglo (2004) document differences in the cost of capital across regions, arguing that some sectors and regions have not been and for a while will not be profitable for private investors. ${ }^{6}$

Unbundling - horizontally and vertically - is another key requirement for privately funded infrastructure projects. This could entail potentially competitive segments under separate ownership from natural monopoly components (Kessides 2004: 3). Kessides (2004: 3) list some examples:

- In electricity, transmission and distribution services should be unbundled from power generation.

- In telecommunications, long-distance, mobile and value added services should be split.

- In natural gas, transmission and distribution should be separated from production, supply and storage.

- In railroads, tracks, signals, and other fixed facilities should be split form train operations and maintenance

According to Kessides (2004: 4), therefore, all infrastructure services should be privatised, except those segments where natural monopoly conditions persist and are unavoidable because of substantial sunk capital.

However, the question remains: If reform is so much more efficient and satisfactory than stateowned monopolies, why the slow progress towards privatising publicly owned entities? Kessides (2004: 4) answers that even though the privatisation model conjures up many benefits and gains, it also poses significant risks if not accompanied by appropriate structural and regulatory safeguards. Whatever the model that may be appropriate in any country at any point in time, the fact that between 1990 and 2001 more than $\$ 750$ billion was invested in 2500 private infrastructure projects in developing and transition economies, of which only 3 per cent went to Africa and the Middle East (Kessides 2004: 11), clearly indicates an under-utilisation of a significant financing source in South Africa's part of the world. Incidentally, most of the $\$ 750$ billion went into telecommunications and power infrastructure.

South Africa's opportunity to mobilise private capital for infrastructure may in a number of respects be more favourable than for many other developing countries in general. First, South Africa has relatively well developed financial markets in which bonds and shares are well traded and in which institutional funds present an important source of finance. Bond financing is one of the most profitable and appropriate financing options. A notable current development which should be pursued in South Africa is the rapid expansion of international project bond markets, which provides developing countries with wider choices in bond financing (Kim, 2005: 8). The South African

\footnotetext{
${ }^{5}$ Subsequently, a strong cyclical recovery in global capital flows to developing countries occurred. Net private flows increased sharply in 2003, reaching $\$ 200$ billion-their highest level since 1998.

6 This is also the impression of Ramamurti and Doh (2004, as quoted by Estache, 2004: 10), who expect infrastructurerelated foreign direct investment to stabilise at lower levels.
} 
municipal bond market has been in existence for many decades and now that the local government finance is steadily being put on a better footing, the rating-based bond issues placed by Johannesburg and Cape Town (the latter forthcoming at the time of writing) open new possibilities.

Second, the government is a potential borrower of good standing, domestically and internationally, ${ }^{7}$ and now has a significant borrowing capacity which may be used without jeopardizing fiscal sustainability. Of course, a budget surplus means that new loans will be unlikely, but the sovereign country rating benefits parastatals in the form of lower international debt cost.

Thirdly, a programme of gradual and phased privatisation of public enterprises has for the past 20 years been running in one form or another, which entailed private equity investment and the competitive restructuring of the relevant economic sectors. Some unresolved issues remain, however, such as the deregulation of Telkom and securing the financial viability of the public transport businesses (rail and air travel).

Fourthly, public-private partnerships ${ }^{8}$ have developed steadily over the past ten years as a method of partnering public and private institutions in delivering services of which the public- and privategoods components are difficult to untangle in the operational and ownership sense of the word, such as water supply and toll roads. Hence, as shown in Table 1, the private finance that is envisaged over the three-year period from 2007/08 onwards. Despite all this, the fact that the investment surge in South African infrastructure occurs at a time when internationally private sector interest in this kind of investment appears to have waned, may well mean that the potential for private financing could be less than what other developing countries experienced during the past 10-15 years.

We maintain, however, that there are more opportunities for private investment in infrastructural development than the Government's tax financing choice offers.

\section{Development finance}

The final source of finance that we explore is that of development agencies. Development finance comes in various forms: concessionary finance (so-called soft loans), loan guarantees and conditional or unconditional grants. In essence, the purpose is to make the project more affordable on account of the agencies' ability to raise funds in a beneficial manner and pass the benefit on to the users of the facility (as in row $d$ of Table 3). The agency could also subsidise the project in such a way that its members contribute from their own resources, in which case they bear part of the cost (as in column 4 of Table 3). Development finance increases fiscal space, ceteris paribus, provided preferences recipient's preferences are not distorted, which in practical terms means that governments should be wary of using donor money to finance projects that have not already been prioritised for normal budgetary funding.

Chatterjee, Sakoulis and Turnovsky (2003, as quoted by Estache, 2004: 9) contrast the effects of a transfer tied to investment in public infrastructure with those of a traditional pure transfer. They show that pure transfers have no growth or dynamic consequences but are always welfare improving. That is not the case for transfers tied to infrastructure, where long-run growth and welfare effects depend on the initial stock of infrastructure as well as cofinancing arrangements.

\footnotetext{
${ }^{7}$ On 7 August 2005 it was announced that the credit rating agency Standard and Poor upgraded South Africa's long term foreign and local currency credit rating from BBB to BBB+ and from A to A+ respectively, citing South Africa's improved macro-economic stability.

${ }^{8}$ Heller (2005b: 13) sounds a warning about the perceived fiscal space created by PPPs. "Governments may believe that public-private partnerships constitute a mechanism for inducing the private sector to finance infrastructure investment that normal budgetary ceilings would limit. There may be some truth to this, particularly if the private sector is more efficient than the public sector in creating and operating infrastructure and public services. Such efficiency gains would imply some additional fiscal space; but for the most part, the savings on infrastructure expenditure will be offset in future years because the private sector would naturally build in the cost of capital into the leasing costs associated with the infrastructure. At a minimum, a government needs to ensure its capacity to absorb the higher expenditure costs in future years, and may need also to take account of the potential contingent risks that may arise in the case of the bankruptcy of the private sector agent."
} 
They also show that a temporary pure transfer has only modest short-run growth effects and leads to a permanent deterioration in the current account, while a productive (i.e. infrastructure related) transfer has significant impacts on short-run growth, leading to permanent improvements in key economic variables including the current account.

What has been the recent experience with regard to development assistance in respect of infrastructure? First we focus on foreign assistance, following which we briefly look at assistance originating inside the country. We observe a number of salient trends.

Official development assistance (ODA) has traditionally been the second largest source of infrastructure financing (Estache, 2004: 9), but this started to decline during the 1990s in the light of great expectations of a large contribution by the private sector. One gets a measure of the extent of this drop from the pattern of infrastructure commitments by multilateral development banks, which fell from $\$ 18.0$ billion in 1996 to $\$ 13.5$ billion in 1999, though by 2002 they had recovered to about $\$ 16.0$ billion. According to Estache (2004: 9), even at its peak, such financing was too small relative to needs.

Globally, the aid industry experiences increasing competition amongst a growing number of donors, with the World Bank Group having lost market share since the mid-1980s (Harford, Hadjimichael and Klein, 2004: 3). Internationally, a number of institutions are sources of development assistance. ${ }^{9}$ Bilateral creditors and donors (from member countries of the OECD Development Assistance Committee), predominantly provide bilateral assistance, with most ODA programmes at the end of the 1990s having been responsible for more than 90 per cent in the form of grants (IDA, 2002: 2). Aid dropped 5.1 per cent from US\$106.8 billion in 2005 - a record high - to US\$103.9 billion in 2006, the first time a reduction was recorded since 1997. Aid to Africa ${ }^{10}$ stalled, despite commitments made by the G8 to double aid to Africa by $2010 .{ }^{11}$

Multilateral institutions, notably the UN, the EU, Bretton Woods Institutions and other multilateral (regional) development banks constitute two distinct groups in terms of nature of financial assistance. The UN and the EU provide almost all of their assistance in the form of grants. By contrast, IDA (the International Development Association of the World Bank), the IMF and the regional development banks provide almost all of their support in the form of concessional lending.

Total aid to sub-Saharan Africa from rich countries represents the bulk of reported net financial flows to the continent, accounting for between 40 per cent and 90 per cent in any given year since 1970. While equity and foreign direct investments have grown significantly since the mid-1990s, they are highly concentrated in a small number of countries. For most countries, official development assistance (ODA) is still the largest single source of capital inflows, contributing nearly half of all net capital flows. Per capita aid flows declined to \$24 per capita in 1999 (nearly half the level seen in the late 1980s) but have since increased to about $\$ 37$ per capita. (Sundberg and Gelb, 2006: 1-2). Non-special-purpose grants constitute what tax payers typically consider to be foreign aid: financing for education, infrastructure, and health projects, as well as budget support for general financing needs. Over time, this share of aid going to project and programme support has fallen. In per capita terms, the decline in project and programme aid during the 1990s was significant, and it has not yet recovered (Sundberg and Gelb 2006: 3). Less than 25 per cent of bilateral aid and 38 per cent of total aid (excluding debt relief) are provided as financing that can be directly used for projects and programmes to build infrastructure, educate children, or reduce the spread of infectious disease. (Sundberg and Gelb, 2006: 5). ${ }^{12}$

\footnotetext{
${ }^{9}$ For our purposes we exclude nongovernmental organizations, not regarding them as a significant source of financing of infrastructure. This does not rule them out as financiers of the occasional project.

${ }_{10}$ Between 1960 and 2004 nearly US $\$ 650$ billion in aid was provided to sub-Saharan African countries by the OECD DAC countries (Sundberg and Gelb, 2006: 1).

${ }_{11}$ As reported in DAC News, 4 April 2007. Available at http://www.oecd.org/dataoecd/56/51/38348577.htm [accessed 7 April 2007]

${ }_{12}$ Donor recipient countries themselves have nullified aspects of donor funding. In 25 countries in Africa, capital flight between 1970 and 1996 was estimated to total $\$ 193$ billion compared with $\$ 178$ billion in external debt, suggesting that several countries in Africa are, ironically, net creditors to rich countries (Boyce and Ndikumana, 2001, as quoted by Sundberg and Gelb, 2006: 7).
} 
The main factor that determines the allocation of IDA resources among eligible countries is each country's performance in implementing policies that promote economic growth and poverty reduction. To link aid to these policies remains a daunting challenge in the light of empirical studies that offer only mild (and not uncontested) support for aid as boosting growth (Heller, 2005a: 2). Moreover, some aid such as in respect of investment in infrastructure, is only likely to show any growth benefits in the long term. Aid as a source of finance can also expose a country's budget to significant volatility and unpredictability (Heller, 2005a: 3). South Africa does not appear on the list of countries qualifying for IDA assistance and can therefore not bargain on any financing from this source (IDA, 2006:1, click on IDA Resource Allocation Index).

The picture is different with regard to development finance in the form of loans, because infrastructure financing constitutes an important part of World Bank business ${ }^{13}$. South Africa has not, however been a major beneficiary in recent time. Currently six projects with World Bank finance are running, of which the committed funding is US\$38m. ${ }^{14}$ The Government's (sometimes understandable) apprehension of World Bank conditionalities used to be an impediment, although the sensitivity may nowadays be less in the light of the country's post-1994 good macroeconomic and fiscal track record. There is a wider window of opportunity, in fact, in that the World Bank has been working closely with the South African Treasury to prepare a Country Partnership Strategy (CPS) (World Bank 2006). The CPS sets out a framework for engagement with South Africa for 2007-2010. It reflects, most importantly, South Africa's own development priorities as set out in ASGISA and South Africa's unique position in the region. Two of the priority areas for World Bank engagement are urban development and public service delivery, both of which link to public infrastructure. By its nature, any such financing will be project specific.

What about the African Development Bank? Although South Africa has been a beneficiary of note ${ }^{15}$ and project finance has been forthcoming, for example in $2004,{ }^{16}$ it did not directly pertain to infrastructure. Given the great development needs on the rest of the continent, the ADB is unlikely to be a significant source of development finance. Moreover, South Africa's chances of mobilising development finance have been obstructed by the view in certain quarters of South Africa as a source of, rather than a destination for development finance. Recently this position has been strengthened further by a discussion document released by the ruling ANC suggesting that the country sets aside between 0.2 and 0.5 per cent of its gross domestic product as development aid to Africa. The existence of the African Infrastructure Investment Fund (AIIF), an unlisted infrastructure fund targeting equity investments in sub-Saharan Africa and sourcing its capital mainly from South African institutional investors ${ }^{17}$ is another case in point.

Strategically the country is likely to access more funds along the loan/equity route than seeking ODA. Given the developed nature of South Africa's financial markets, sufficient reliable financial information can be generated to ensure that projects be financed with high financial and socioeconomic returns. All multilateral and most bilateral donors use cost-benefit analysis to estimate such returns. Among World Bank infrastructure projects that had at least 95 per cent of loan commitments disbursed between 1999 and 2003, the average economic return was 35 per cent, with a spread ranging from 19 per cent for water and sanitation projects to 43 per cent for transport (Estache, 2004: 4). It is imperative that South Africa approaches prospective donors with

\footnotetext{
${ }^{13}$ A World Bank website (http://web.worldbank.org/WBSITE/EXTERNAL/PROJECTS) search of infrastructure projects returns no less than 2600 results out of more than 9500 projects registered on their website, in which they were involved since 1947.

${ }_{14}$ As shown on the World Bank's website [available at http://worldbank.org - accessed 11 May 2007].

${ }^{15}$ Between 1967 and 2005 loans and grants to the amount of US $\$ 350,9$ were made available to South Africa. See African Development Bank website, available at

http://www.afdb.org/portal/page? pageid=473,969532\& dad=portal\& schema=PORTAL - accessed 11 May 2007.

${ }^{16}$ For a list of approved country projects financed by the African Development Bank in 2004 and 2005, see African Development Bank (2007).

${ }_{17}$ The AllF was established in early 2004 as a joint venture between Macquarie Bank and Old Mutual Asset Managers of South Africa. In August 2004, AlIF had raised R 1320 million from a range of leading South African institutional investors. AlIF is an unlisted infrastructure fund investing predominantly in South African infrastructure projects, including roads, airports, power, telecommunications, rail, ports, water and social infrastructure. Current investments include a $6 \%$ stake in Trans African Concessions (Pty) Limited, and a 10.2\% stake in N3 Toll Concessions. (See "African infrastructure funds" available at http://www.macquarie.com.au/au/corporations/sfpc/saif/overview.htm [accessed 9 April 2007]).
} 
proper estimates of project returns, with due cognisance of demands from rivalry countries. Projects approved on the basis of grant funding should not be discarded, but aspects of government failure as well as donors' own interest may jeopardise the choice of projects that enhance economic growth and underpin sustainable poverty reduction.

The Development Bank of Southern Africa (DBSA) is an important domestic source of infrastructural finance (grantor, lender, investor and underwriter of guarantees): its declared purpose is to accelerate sustainable socio-economic development by funding physical, social and economic infrastructure within its mandated area of the Southern African Development Community (SADC). The 2005/06 list of approved projects (DBSA, 2007) shows local governments to be the major client (which inter alia include a loan facility of R500m each for the city of Tshwane and the eThekwini Municipality and R600 million for the City of Cape Town for infrastructural development), with educational institutions and nongovernmental organisations also featuring occasionally. An interesting example of the multifaceted nature of their support is the financing that is under negotiation in respect of the public-private partnership which the Department of Foreign Affairs is establishing to erect their new building. The DBSA offered a package which entails a combination of a technical assistance grant, an empowerment equity loan funding to the BEE parties, performance bond counter guarantees to sub-contractor BEE shareholders, and a project financing loan to the private party as part of a syndicate of lenders arranged by a commercial bank.

DBSA has aligned itself with the ASGISA investment drive, inter alia through the Local Investment Agency created in partnership with Old Mutual and a targeted infrastructure development programme involving special development credits (DBSA, 2006: 15). Investments in human capital for planning, project management and technical capacity in municipalities are spearheaded by the Bank's SiyenzaManje, in tandem with the Government's Project Consolidate and the Infrastructure Delivery Improvement Programme (National Treasury, 2007: 131-132). If the financing levels of the past five years could be maintained - on average DBSA approved (loans and investments) of R12,73 billion per annum over the five-year period $2001-2006^{18}$ - the Bank will remain an important source of finance especially for institutions that will be unable to directly access the financial markets.

\section{Illustrating the combination of financing options: four case studies}

To illustrate the implementation of various financing options in South Africa, the finance structure of four infrastructure projects in South Africa is considered. Table 4, similar to Table 3, shows where each of the four case study projects is located on the financing and payment map.

\footnotetext{
${ }^{18}$ Data obtained from the DBSA.
} 


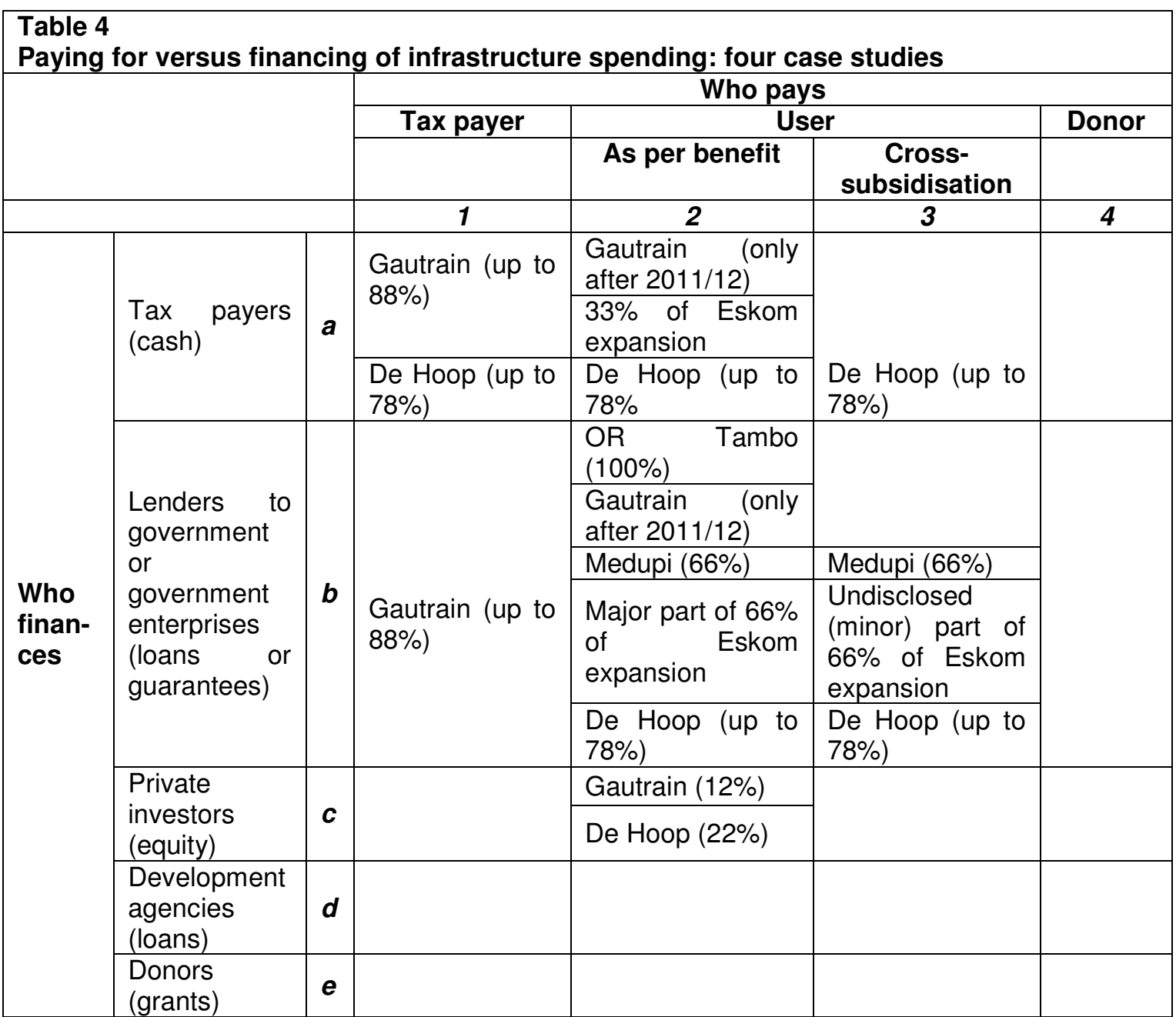

The purpose is to illustrate the spectrum of options already followed in South Africa and suggest that each and every prospective infrastructure project be systematically analysed with a view to the appropriate combination of financing and payment options. It is particularly important that the opportunity cost of equity gains in terms of efficiency loss be properly analysed and disclosed. It would also add a lot to public understanding of the implications of the prospective investment in South African infrastructure if the National Treasury could map out all the different projects according to Table 4.

\section{OR Tambo International Airport}

The Airports Company of South Africa (ACSA), owned 20 per cent by the Public Investment Corporation and the rest by government, is undertaking numerous projects ahead of the 2010 soccer World Cup. Most of these developments are at the three major South African airports, Johannesburg (OR Thambo), Cape Town and Durban (King Shaka). Close to R4 billion is set aside for projects at OR Thambo, which includes a new central terminal building (of R2 billion), a new international pier (R535 million) and complementary Echo Apron (R219 million) and a new multistorey parkade (R470 million) that will provide 5200 additional parking bays (ACSA website). In total, the company will invest up to R5.2 billion in new and upgraded facilities (ACSA, 2006), although this number has since inflated to R8.5 billion for the period up to 2013 (Lünsche, 2007a).

To finance the expansion programmes, ACSA aims to issue a R12 billion long-term bond, structured in various tranches, with the first bond of R2 billion having been issued in April 2007 (Lünsche, 2007a). The company has an upper-grade rating and its weighted average cost of capital is relatively inexpensive (Lünsche 2007a). To service the bond, ACSA will rely on its tariff income which is earned through a percentage of the airport tax and landing fees. This locates this programme in cell b2 of Table 4. These tariffs comprise 55 per cent of ACSA's total revenue (ACSA, 2006), the major other revenue sources being retail rentals (18\%), advertising (5,6\%), 
parking $(10,8 \%)$, and car hire $(5,2 \%)$ (ACSA, 2006). ACSA is budgeting for an 8.5 per cent rise in tariff income in the 2007/2008 financial year (Lünsche, 2007a), implying that, given expected inflation, the airport use is becoming relatively more expensive.

ACSA is almost an atypical example of a parastatal infrastructure provider. The company is earning profits, puts a high emphasis on maintenance and plans well in advance (even though it may have underestimated the growth in passengers). ${ }^{19}$ Moreover, its financing option of long-term borrowing and debt servicing through user charges complies with efficiency considerations. OR Tambo Airport is therefore located in cell $b 2$.

One reason for the good performance may be that ACSA has no responsibility to increase airport use on equity grounds; whereas most other infrastructure indicators must reflect the access of its services to the poor, ACSA is under no obligation to "make airport use available to all". This ensures that it is the customers who end up paying for the improvements and expansions at airports through tariffs on plane tickets. Furthermore, by issuing bonds, ACSA is also ensuring that tomorrow's customers ultimately pay for a service they will receive, while current customers are not burdened with high tariffs that they ultimately will not enjoy the services of. With little or no crosssubsidisation, between higher and lower income users or today's consumers and tomorrow's consumers, ACSA is a good example of the allocative efficiency created by the benefit principle at work.

\section{Gautrain Rapid Rail Link}

The R25,1 billion Gautrain Rapid Rail Link is an $80 \mathrm{~km}$ mass-transit system in Gauteng that will ultimately link Johannesburg, Pretoria and the OR Tambo International Airport. The project has been structured as a public-private partnership, with Bombardier Transportation (25\%), Bouygues Travaux Public (25\%), Murray \& Roberts $(25 \%)$, and SPG $(25 \%)$ as shareholders in the Bombela Concession Company.

According to the Gauteng Finance Minister's 2007 Budget Speech, the public sector has committed R22 billion to the project, with the contribution of the private sector set at R3 billion (Gauteng Provincial Government, 2007). The private contribution is financed through loans from a joint agreement between Bombela Concession Company and First National Bank and Standard Bank. Furthermore, SPG (Strategic Partners Group), a broad based black economic empowerment company, is funded by the Industrial Development Corporation and the Development Bank of Southern Africa. According to Olivier (2007), "the two development finance institutions had agreed to provide SPG with a performance bond in the amount of R220-million and a loan facility worth R196-million, which is intended to assist SPG in its acquisition of equity in Bombela".

According to the National Budget (National Treasury, 2007), the national and provincial government will each contribute R8.8 billion over the Medium Term Expenditure Framework period, and the private sector contribution will amount to R2.1 billion. Between 2006/2007 and 2011/2012 the project cost will total R22.6 billion. According to the National Budget (National Treasury, 2007: 59), after 2011/12 the project will move into the operational phase and costs will be covered by operating revenue. This suggests that the initial R22.6 billion will not be financed through future user charge repayments, with taxpayers, therefore, bearing the brunt of design and construction costs. There is no indication that government borrowing will increase and to which degree future taxpayers will supplant current taxpayers in financing the Gautrain project. The private partners would only invest if by their estimation an appropriate return is obtained. Such revenue will be in the form of user-charges, with no or little projected cross-subsidisation. ${ }^{20}$ We therefore locate the financing-payment of this project in five different cells: $a 1$ and b1 (because up to $88 \%$ of project cost will be financed by government through current or future taxes), c2 (because $12 \%$ of project

19 The 2006 SAICE report card, published by the South African Institute of Civil Engineers, gives ACSA a very good "B" rating, emphasising that "the key factor pertinent to the state of ACSA's infrastructure has been its strong financial state, and in particular its ability over the years to budget adequately for maintenance and replacement" (SAICE, 2006).

${ }_{20}$ While donor funding and loan facilities do play a role within the Bombela consortium, their main aim is to act as platform for the development of BBBEE agents and therefore should not be included as part of this analysis. 
cost will be financed through private investment), and a2 and b2 (because only after 2011/2012 will user charges pay for management and operation).

Of course, the envisaged public spending could be justified if the government believes that there are positive externalities that accrue from the investment in the Gautrain project. This is possible through the direct and indirect positive impact infrastructure investment has on economic growth. Yet, these benefits will only accrue in the long-run with future taxpayers to benefit. This suggests that loan finance would be more appropriate than the R16 billion to be financed from current tax revenue, which would locate the programme in cell $b 1$.

\section{Eskom expansion programme}

Eskom, a South African electricity public utility, aims to spend more than R150 billion over the next five years to increase its electricity generation capacity and improve transmission and its distribution network. Their underestimation of the South African economic growth has created shortages in electricity supply with consequent power-outages in a number of provinces. This is due not only to the stagnant level of electricity generation, but also the deteriorating condition of transmission and distribution networks.

During May 2007, Eskom received the go-ahead for the construction of the first coal-fired power plant in nearly two decades, in Lephalale, Limpopo. The power plant, named Medupi, is set to commence operation in 2011 and will eventually add $4500 \mathrm{MW}(11.5 \%$ of current capacity and $7.4 \%$ of projected capacity) to the electricity network. The projected construction cost is R66 billion (Creamer, 2007). Medupi will be followed by an even bigger plant, codenamed Project Bravo, planned for $2013 .^{21}$

According to Lünsche (2007b), Eskom will finance the R150 billion capital expenditure through South African and offshore debt markets (R100 billion) and the remaining from Eskom's cash flow (which is projected to increase with proposed higher tariffs in 2008 and 2009). According to Eskom's finance director, two-thirds of the borrowings will be raised on the South African bond market, with the offshore borrowing programming comprising export credit financing and foreign debt (Lünsche, 2007b: 18).

Eskom is gearing up to expand its generation capacity at a rapid pace. The increase in capital expenditure is to be financed mostly through debt financing, both on the South African bond market and offshore. This debt will be serviced by an increase in tariffs for future users of electricity, which complies with criteria of efficiency. However, Eskom is also obliged to ensure that access to electricity improves, as there are especially rural areas with no electricity supply and assuming that marginal cost pricing would be unaffordable. This will probably ensure some degree of crosssubsidisation. The extent is unknown. The project is thus located in cells $a 2, b 2$ and $c 2$.

\section{De Hoop dam}

De Hoop is a R7.9 billion dam and water reticulation project undertaken by the Department of Water Affairs and Forestry. The dam will enable the development of the rural communities surrounding the dam, deliver water to Mokopane and surrounding platinum mines, enable Eskom to consider a hydro plant, and facilitate the development of Burgersfort (Schneider, 2007: 50). Water is considered a resource for mining industries in the Limpopo province, and with current dam capacity on average at 59 per cent, the availability of a dependable water source could spark investor interest (Hill, 2007).

According to Schneider (2007: 50), construction of the dam will cost government R1.2 billion, with groundwork having started in March 2007. Government is also responsible for the bulk raw water distribution network at an additional R3.7 billion (phase 2), with municipalities responsible for another R3 billion to construct pump stations, water treatment plants, pipelines and reservoirs for

${ }^{21}$ Only $20 \%$ of the R150 billion capital expenditure programme is devoted to investments in Medupi and Project Bravo (Lünsche, 2007a). 
potable water (Schneider 2007: 50). According to Schneider (2007: 50), mining houses will contribute roughly 47 per cent of the capital costs of phase 2 , calculated as a percentage of the water they use from the dam, which equals R1.74 billion (22\%) of the total bill of R7.9 billion.

It is unclear how the government (both the Department of Water Affairs and Forestry and the local municipalities) will finance the capital expenditure. Conjecture suggests that most of it will probably be through current expenditure i.e. through the general revenue fund of national government and user charges with cross-subsidisation at local municipality level. The De Hoop dam is thus located in cells a1, a2, b2 and c2. Again, there is no clear economic justification for current taxpayers to pay, especially at the local municipality level where loan financing is an uncommon phenomenon.

\section{Conclusions}

In this paper we presented a range of financing and payment options that could be considered with respect to the SA Government's infrastructure investment plans. We suggested that the wider application of the benefit principle of allocative efficiency should increase the fiscal scope at national level. We have developed a classification system that enables a systematic mapping of all the prospective projects that should aid the macro planning and assist in any analysis of the financial implications of project financing and cost recovery at all levels of government.

\section{REFERENCES}

ACSA (Airports Company of South Africa). (2006). Annual Report. Available online: http://www.acsa.co.za/home.asp?pid=517 [accessed 9 July 2007].

. (2007). Projects. Available online: http://www.acsa.co.za/home.asp?pid=2781\# [accessed 9 July 2007].

African Development Bank. (2007). ADB Projects. Available at http://www.afdb.org/portal/page? pageid=473,1050321\& dad=portal\& schema=PORTAL [accessed11 May 2007].

Alexander, I and Estache, A. (1999). Infrastructure Restructuring and Regulation - Building a base for sustainable growth. Prepared for the IDRC/TIPS conference presentation: September $19^{\text {th }}$ to $22^{\text {nd }} 1999$.

Black, PA, Calitz, E, Steenekamp, TJ and Associates. (2005). Public Economics. 3rd edition. Cape Town: Oxford University Press.

Boyce, J and Ndikumana, L. (2001). Is Africa a Net Creditor? New Estimates of Capital Flight from Severely Indebted Sub-Saharan African Countries, 1970-1996. Journal of Development Studies 38 (Dec):27-56.

Calitz, E and Siebrits, FK. (2005). Fiscal Policy. In PA Black, E Calitz. TJ Steenekamp \& Associates. Public Economics. 3rd edition. Cape Town: Oxford University Press: 238-271.

Chatterjee, S, Sakoulis, G and Turnovsky, S. (2003). Unilateral Capital Transfers, Public Investment, and Economic Growth. European Economic Review 47 (6): 1077-1103.

Creamer, T. All systems go for R66bn coal-fired power station build, SA's first in two decades. Engineering News. 8 May 2007. Available online: http://www.miningweekly.co.za/article.php?a id=108490 [accessed 10 July 2007].

Da Silva LC, Estache A and Järvelä S. (2006). Is debt replacing equity in regulated privatized infrastructure in LDCs? Utilities Policy 14 (2006) 90-102. Available at www.sciencedirect.com [accessed 9 April 2007]. 
DBSA (Development Bank of Southern Africa). (2007). Annual Report 2005/06.

Estache, A. (2004). A Selected Survey of Recent Economic Literature on Emerging Infrastructure Policy Issues in Developing Countries. Unpublished working paper. Washington, DC: World Bank.

Estache, A. and Pinglo, ME. (2004). Are returns to Public-Private Infrastructure Partnerships in Developing Countries Consistent with Risks since the Asian Crisis. World Bank, PR Working Paper series Number 3373. Washington, DC: World Bank.

Gauteng Provincial Government. (2007). Budget Speech 2007. Available online: http://www.finance.gpg.gov.za/budget\%20speech.pdf [accessed 9 July 2007].

Harford, T, Hadjimichael, B and Klein, M. (2004). Aid Agency Competition. Public Policy Journal 277 (October). World Bank. Available at h t t p: / / r u . w or ld bank o o g / P u b l i c P o li c y J o u r n a I [ [accessed 7 April 2007].

Heller, P. (2005a). Making AID work. Finance and Development 42(3): 11 pages. Available at $\mathrm{h} t \mathrm{t} p$ : / / r u . world bank. org / P ublic Polic y Journal [accessed 7 April 2007].

. (2005b). Understanding Fiscal Space. IMF Policy Discussion Paper PDP/05/4. Washington, DC: IMF. March.

Hill, M. (2007). R5bn De Hoop dam to be development 'catalyst'. Engineering News. Available online: http://www.miningweekly.co.za/article.php?a id=105962 [accessed 10 July 2007].

IDA (International Development Association). (2002). IDA, Grants and the Structure of Official Development Assistance.

(2006). How IDA Resources are Allocated. Available at http://web.worldbank.org/WBSITE/EXTERNAL/EXTABOUTUS/IDA/0,,contentMDK:20052347 m enuPK:2607525 pagePK:51236175 piPK:437394 theSitePK:73154,00.html [accessed 9 April 2007].

Kessides, I. (2004). Reforming Infrastructure: Privatization, Regulation, and Competition. A World Bank Policy Research Report. Washington D.C.: World Bank.

Kim, Y-H. (2005). Financing Infrastructure Development: Asian Developing Countries Need to Tap Bond Markets More Rigorously. ERD Policy Brief no. 34. Asian Development Bank. February.

Kirkpatrick, C, Parker, D and Zhang, Y-F. (2006). Foreign direct investment in infrastructure in developing countries: does regulation make a difference? Transnational Corporations 15(1):143171. April.

Lünsche, S. (2007a). Prepare for a comfy landing. Supplement to the Financial Mail. Special Report: Infrastructure. June 22 2007, pp. 48.

Lünsche, S. (2007b). Keeping up, powering on. Supplement to the Financial Mail. Special Report: Infrastructure. June 22 2007, pp. 16-18.

National Treasury. (2007). National Budget Review. National Treasury: Pretoria.

Olivier, M. (2007). Gautrain consortium secures R3bn loan. Engineering News. Available online: http://www.engineeringnews.co.za/article.php?a id=100763 [accessed 9 July 2007].

Rosen, Harvey S. (2005). Public Finance. 7th edition. Singapore: McGraw-Hill.

RSA. (2006). Accelerated and Shared Growth Initiative for South Africa (ASGISA). Available on 
line: http://www.info.gov.za/asgisa/asgisa.htm [accessed 30 July 2007].

SAICE (South African Institution of Civil Engineering). 2006. The SAICE Infrastructure Report Card for South Africa: 2006. Available online: http://www.civils.org.za/ [Accessed 14 June 2007].

Schneider, M. (2007). Floods of investment. Supplement to the Financial Mail. Special Report: Infrastructure. June 22 2007, p. 50.

Siebrits, FK and Calitz, E. (2004). Should South Africa adopt numerical fiscal rules?. South African Journal of Economics 72(4):759-782.

Smith, Adam. (1776). An Inquiry into the Nature and Causes of the Wealth of Nations. 2 Vols, Everyman's Library. London: Dent \& Sons (1904).

SUDEO International Business Consultants. (2007). Draft Research Report for the Infrastructure Inputs Sector Strategy. Commissioned by The Presidency, Republic of South Africa. Pretoria: The Presidency.

Sundberg, M and Gelb, A. (2006). Making Aid Work. Finance and Development 43(4): 10 pages. Available at http://www.imf.org/external/pubs/tt/fandd/2006/12/sundberg.htmhttp://www.imf. org/external/pubs/ft/fandd/2006/12/sundberg.htm [accessed 7 April 2007].

World Bank. (2003). Private Participation in Infrastructure: Trends in Developing Countries, $1990-$ 2001. Washington, D.C.: World Bank and Public Private Infrastructure Advisory Facility.

. (2004). Global Development Finance: Harnessing Cyclical Gains for Development. Washington, DC: World Bank. Available at www.worldbank.org.

(2006). South Africa Country Brief. Washington, DC: World Bank. November. Available at http://web.worldbank.org/WBSITE/EXTERNAL/COUNTRIES/AFRICAEXT/SOUTHAFRICAEXTN /0,,menuPK:368086 pagePK:141132 piPK:141107 theSitePK:368057,00.html [accessed 24 April 2007]. 